\title{
The Impact of Product Diversification Strategy on Brand Loyalty: A Case Study
}

\author{
Yashasvi Kanodia \\ NMIMS’ Kirit P. Mehta School of Law, Mumbai, Maharashtra, India.
}

CITATION: Kanodia, Yashasvi (2020), "The Impact of Product Diversification Strategy on Brand Loyalty: A Case Study", MERC Global's International Journal of Management, Vol. 8, Issue 3, pp. 89-93.

ARTICLE HISTORY: Submitted: March 24, 2020, Revision received: April 25, 2020, Accepted: May 13, 2020

\section{ARTICLE TYPE: Review paper}

\begin{abstract}
"If people believe they share values with a company, they will stay loyal to the brand." This statement by Howard Schultz carries profound truth in it. For any brand and its products to be successful in the market, they should be able to satisfy its consumers. Customers can be retained only when the company identifies the behavioural purchasing patterns of the consumers in a world constantly stuck among changing trends, technology and lifestyle. The purpose of this research study is to investigate the direct relationship between the unique selling methods adopted by Colgate and their diversification in the products that they offer and their combined effect on brand loyalty. This paper provides a preliminary understanding of the various factors that have contributed to the brand loyalty of Colgate over the decades and why people continue to trust the brand despite having the discretion to switch to rival brands at almost similar prices. The study highlights the significance of the effect of brand loyalty on the sale of its products and how by adopting different marketing strategies, brands can retain old customers and attract new ones.
\end{abstract}

KEYWORDS: Brand loyalty, Colgate, Unique selling methods, Segmentation strategy, Demographics, Product diversification.

\section{REFERENCES}

1. Bartleby Research (2020), Media Advertising - Colgate Advertising Strategies Over the Years, available at: $\quad$ https://www.bartleby.com/essay/Media-Advertising-Colgate-Advertising-Strategies-Over-theFKPJQGYTC (accessed 20 March, 2020).

2. Bhatnagar, V. (2011), "Brand Choice and Brand Loyalty of Rural Consumers- A study with special reference to branded toothpastes", National Seminar held at Institute of Commerce and Management, Jiwaji University, Gwalior, M.P., At Gwalior.

3. Bol, Joey (2016), "Colgate Marketing Plan", working paper, University of Applied Sciences, Leiden.

4. Hirschsfeld, J. (2019), "Not All Cultures Use Toothbrushes. But How Effective Are Alternative Methods?", available at: https://www.sciencealert.com/how-effective-are-these-traditional-teeth-cleaningtechniques, accessed 22 March, 2020).

5. Kumar, S. and Advani, Jai. (2005), "Factors affecting Brand Loyalty: A Study in an Emerging Market on Fast Moving Consumer Goods", Journal of Customer Behaviour. Vol. 04. pp. 251-275.

6. Maina, M. F. (2007), "Factors that Determine Brand Loyalty: The Case of Toothpaste Users in Westlands, Nairobi, Kenya", working paper, School of Business, University of Nairobi.

7. Morgan, P. (2015), "Colgate Has the Highest Brand Penetration in the World", available at: https://marketrealist.com/2015/07/colgate-highest-brand-penetration-world/, accessed on 21 March, 2020.

8. Pai, S. (2017), "International and Domestic Marketing Strategies of Colgate", working paper, Mulund College of Commerce, University of Mumbai. 
9. Priyadarshini, R.; Vignesh, N.; Nelson, E. J. and Muthu Kumar, M. (2018), "A Study on Customer Attitude towards Colgate Toothpaste with reference to Coimbatore District", International Journal of Advance Research and Innovative Ideas in Education, Vol. 04, Issue 01, pp. 425-430.

10. Quelch, John A. and Rodriguez, Margaret L. (2017), "Colgate-Palmolive Company: Marketing AntiCavity Toothpaste", Harvard Business School Case, Vol. 09, pp. 515-550.

11. Raturi, Sushil and Raturi, Rakhi (2019), "Impact of Brand Attributes on Consumers' Conative Attitude A Study for Indian Apparel Industry”, MERC Global's International Journal of Management, Vol. 7, Issue 4, pp. 307-312.

12. Sharma, Satakshi and Lakhawat, Pradhyuman Singh (2019), "Retail Ethics and Brand Loyalty: A Critical Analysis”, MERC Global's International Journal of Management, Vol. 7, Special Issue 1, pp. 67-71.

13. Thanwarani, Amber (2013), "Consumer Personality Trait, Brand Persona and Brand Loyalty: A Pragmatic Study of Colgate Toothpaste Buyer”, International Journal of Humanities and Management Sciences, Vol. 01. pp. 155-158.

14. University of the West Indies (2020), Brand loyalty is another driver of this segment, available at: https://www.coursehero.com/file/p6idoof/Brand-loyalty-is-another-driver-of-this-segment-Colgate-hasbeen-the-oldest/ (accessed 22 March, 2020).

15. Williams, S. (2014), “Colgate or Crest: Can You Guess Which Is America's Favourite Toothpaste?", available at: mailto:https://www.fool.com/investing/general/2014/09/12/colgate-or-crest-can-you-guesswhich-is-americas-f.aspx, accessed 21 March, 2020. 